\title{
STUDIES ON THE CONTROL OF MYELINOGENESIS
}

\section{Neuronal Induction of Schwann Cell Myelin-specific Protein Synthesis during Nerve Fiber Regeneration ${ }^{1}$}

\author{
M. J. POLITIS, ${ }^{2}$ N. STERNBERGER, ${ }^{*}$ KATHY EDERLE, AND PETER S. SPENCER
}

Departments of Neuroscience and Pathology, Institute of Neurotoxicology, Albert Einstein College of Medicine, Bronx, New York 10461 and ${ }^{*}$ Center for Brain Research, University of Rochester Medical Center, Rochester, New York 14627

Received June 9, 1981; Revised April 2, 1982; Accepted April 5, 1982

\begin{abstract}
The temporal sequence of axon-Schwann cell interaction during regeneration is examined in cat tibial nerves surgically denervated for 8 weeks and, subsequently, coapted to a freshly severed peroneal nerve for 3 weeks. Prior to association with regenerating axons, Schwann cells resident in denervated and reinnervated stumps failed to synthesize proteins co-migrant with $\mathrm{P}_{0}, \mathrm{P}_{1}$, and $\mathrm{P}_{2}$ myelin proteins in contrast to normal nerves. Axonal association with Schwann cells stimulated synthesis of amino acid-labeled proteins co-migrating with myelin-specific proteins prior to elaboration of myelin lamellae. Radioactivity from these peaks was precipitated by antibodies raised against myelin-specific proteins. The synthesis of $P_{1}$ and $P_{2}$ proteins was evident before $P_{0}$ synthesis in reinnervated stumps. Immunocytochemical staining with antibody to $\mathrm{P}_{0}, \mathrm{P}_{1}, \mathrm{P}_{2}$, and myelinassociated glycoprotein (MAG) appeared only after myelin lamellae had been formed. These data suggest that Schwann cells: (a) synthesize proteins co-migrant with $\mathrm{P}_{1}, \mathrm{P}_{2}, \mathrm{P}_{0}$, and MAG in normal cat nerves; $(b)$ cease detectable manufacture of these proteins after axonal loss; $(c)$ regain their capacity to synthesize these proteins upon re-establishment of axonal association; and $(d)$ during regeneration, express the synthesis of $P_{1}$ and $P_{2}$ before that of $P_{0}$.
\end{abstract}

Earlier studies in this series of papers and from other laboratories established that axons dictate the myelinating behavior of Schwann cells during nerve fiber regeneration (reviewed by Spencer, 1979). The mechanism of regulation and the sequence of biochemical events leading to myelinogenesis are not defined, previous papers describing peripheral nerve fiber development and regeneration having focused on morphological analysis of the isolation, envelopment, and elaboration of myelin lamellae by the Schwann cell (e.g., Webster et al., 1973; Schröder, 1975). Some of the many unresolved biochemical questions can now be addressed with the aid of a new in vivo model of nerve regeneration which spatially separates the temporal sequence of axon-Schwann cell interaction and avoids the reactive and degenerative

\footnotetext{
${ }^{1}$ We wish to thank Dr. Steven Cohen for donating antiserum to myelin basic protein and Monica Bischoff for preparation of the figures and legends. These studies were supported by Grant NS 13106 from the National Institutes of Health. M. J. P. was supported by National Institutes of Health Training Grant NS 07098.

${ }^{2}$ To whom correspondence should be addressed at Institute of Neurotoxicology, Albert Einstein College of Medicine, 1300 Morris Park Avenue, Bronx, NY 10461.
}

changes that usually accompany this process (Politis and Spencer, 1981).

The model is established by a two-stage surgical manipulation of tibial and peroneal nerves in the hindlimb of the cat. Initially, the tibial nerve is transected to stimulate the loss of axons and myelin from the distal stump and the proliferation of Schwann cells (Spencer et al., 1979, 1981). After several weeks, viable Schwann cells, which do not elaborate myelin, populate the nerve stump. These Schwann cells then are challenged with regenerating axons by coapting the tibial nerve distal stump to the proximal stump of the neighboring peroneal nerve. After 3 weeks of axonal regeneration, the temporal sequence of cellular events associated with axon-Schwann cell contact and myelinogenesis in the tibial nerve stump is separated reproducibly in a proximal-distal gradient divisible into three well defined regions: $(a)$ a proximalmost, myelinated zone $(\mathrm{M}$; between 0 and 1.5 to $2 \mathrm{~cm}$ from the position of peroneal-tibial coaptation) containing Schwann cells beginning to elaborate myelin lamellae around some regenerating axons; $(b)$ an intermediate, relatively immature, contact zone $(\mathrm{C}$; between 1.5 to 2 and $6 \mathrm{~cm}$ from the site of coaptation) exhibiting Schwann cells enveloping axons prior to the formation of myelin 
lamellae; and (c) a distal, noncontact zone (NC), where axons have yet to advance and Schwann cells appear dormant. A previous detailed description of this model demonstrated that the position of separation between zones $\mathrm{C}$ and $\mathrm{NC}$ is defined precisely by the distal limit of movement of a radioactive label incorporated into the fast axonal transport system of the regenerating axons and that the division between zones $\mathrm{M}$ and $\mathrm{C}$ is dictated by the border between regions with myelin lamellae and those without (Politis and Spencer, 1981).

The biochemical properties of the three clearly defined zones can be examined and compared by sampling appropriate portions of the reinnervated nerve stump. For example, incubation of tissue from the three zones in tritiated thymidine demonstrated a significant and reproducible increase of thymidine incorporation in the myelinated and contact zones relative to that in the noncontact zone (Pellegrino et al., 1980). These findings demonstrated that mitotic activity is induced when regenerating axons reach Schwann cells.

The present study uses this new model of peripheral nerve regeneration to characterize Schwann cell protein synthesis as a function of axon contact and the formation of myelin lamellae. Four principal questions are addressed: $(a)$ do Schwann cells which have lost axonal apposition synthesize myelin proteins? $(b)$ Do regenerating axons initiate changes in Schwann cell protein synthesis? (c) Can myelin protein synthesis be detected before the elaboration of myelin lamellae? $(d)$ In what sequence are specific myelin proteins synthesized?

A preliminary report of this work has appeared elsewhere (Politis et al., 1980).

\section{Materials and Methods}

Surgical procedure. A total of 11 cats, each weighing 2.5 to $3.5 \mathrm{~kg}$, was used for these experiments. For surgery, the animals were anesthetized deeply with sodium barbitone, and bilateral procedures were carried out under aseptic conditions.

Complete denervation of the tibial nerve was achieved by transecting the nerve $2 \mathrm{~cm}$ below the sciatic notch, ligating its cut ends with $4 / 0$ suture thread, and securing both nerve stumps $1 \mathrm{~cm}$ apart onto underlying muscle (Fig. 1, step 1). Morphological examination of the distal stumps 7 to 8 weeks post-transection revealed axon- and myelin-free Schwann cells aligned longitudinally into columns (bands of Büngner), each delimited by a conduit of basal lamina.

Regenerating axons were introduced into tibial nerve distal stumps 7 weeks after nerve transection. To promote axon penetration, the ligated proximal $1-$ to $1.5-\mathrm{cm}$ portion of the distal nerve stump was removed and discarded. The peroneal nerve then was severed and its proximal stump was ligated to the tibial nerve distal stump with the aid of four or five $9 / 0$ epineurial sutures (Fig. 1, step 2). Three weeks later, the animals were reancsthetized and the fuscd peroneal-tibial nerve was removed.

The tibial portion of the fused nerve was divided into five segments, each $2.5 \mathrm{~cm}$ in length, for incubation in tritiated amino acids or fucose. These segments were chosen on the basis of previous light and electron microscope studies which had revealed three distinct zones (proximal myelinated, intermediate contact, and distal noncontact) of Schwann cell differentiation (Figs. 1, $r i g h t$, and 2 to 4). (a) The first (proximalmost) $2.5-\mathrm{cm}$ segment (M) comprised all of the myelinated zone plus a small portion of the contact zone. Sampling this length of nerve insured the absence of myelin lamellae in scgment $C_{1}$. (b) The second segment $\left(C_{1}\right)$ contained Schwann cells at an advanced stage of axonal association prior to the formation of myelin lamellae. (c) The third segment $\left(\mathrm{C}_{2}\right)$ included Schwann cells at an early stage of axonal association and, distally, a portion of the proximal noncontact zone. Sampling this length of nerve insured the absence of axons in segment $\mathrm{NC}_{1} .(d$ and $e)$ The fourth and fifth segments $\left(\mathrm{NC}_{1}\right.$ and $\left.\mathrm{NC}_{2}\right)$ contained Schwann cells free of regenerating axons (Fig. 2). The absence of axons from these two segments was demonstrated previously by electron microscopy and by the disappearance of an axonally transported radiolabel at the interface between zones $\mathrm{C}_{2}$ and $\mathrm{NC}_{1}$ (Politis and Spencer, 1981).

Control material consisted of $2.5-\mathrm{cm}$ lengths of intact sciatic or brachial nerves and tibial nerve distal stumps denervated for 10 weeks.

Assessment of protein synthesis. Eleven reinnervated tibial nerves were used. Nerve segments a to e from each of four nerves were incubated in $\left[{ }^{3} \mathrm{H}\right]$ ieucine $(300 \mu \mathrm{Ci}, 40$ to $60 \mathrm{Ci} / \mathrm{mmol}$; Amersham Corp.), four were incubated in $\left[{ }^{3} \mathrm{H}\right]$ fucose ( $300 \mu \mathrm{Ci}, 20 \mathrm{Ci} / \mathrm{mmol}$; Amersham Corp.), and three were incubated in $\left[{ }^{3} \mathrm{H}\right]$ tryptophan $(150 \mu \mathrm{Ci}, 27$ $\mathrm{Ci} / \mathrm{mmol}$; Amersham Corp.). The latter amino acid was used because it is not incorporated into histones which migrate in the vicinity of myelin basic proteins (H. Agrawal, personal communication). To facilitate incorporation and subsequent analysis, endoneurial tissue was plucked rapidly from the unwanted nerve sheath (perineurium plus epineurium) with the aid of watchmaker's forceps and a stereoscopic dissecting microscope. Approximately $90 \%$ of the cells in denervated distal stumps are Schwann cells (Spencer et al., 1979). These tissue samples were incubated in a shaking water bath at $37^{\circ} \mathrm{C}$ for $2 \mathrm{hr}$ in $3 \mathrm{ml}$ of oxygenated $\left(95 \% \mathrm{O}_{2}, 5 \% \mathrm{CO}_{2}\right)$ Krebs' buffer containing $2 \mathrm{mg} / \mathrm{ml}$ of glucose and $0.1 \mathrm{mg} / \mathrm{ml}$ of chloramphenicol. The latter was added to inhibit any mitochondrial protein synthesis in axons or Schwann cells. After incubation was complete, further amino acid incorporation was stopped by several washes of cold buffer.

Incubated nerve segments were prepared for slab gel electrophoresis by homogenization and partial delipidation of the homogenate with $3: 2$ ether:ethanol. Sodium dodecyl sulfate-polyacrylamide gel electrophoresis (SDSPAGE) was performed using a $3 \%$ stacking gel and a $12 \%$ running gel by a modification of the methods of Laemmli (1970), Greenfield et al. (1973), and Inouye (1971). All homogenates from each reinnervated and control nerve, coupled with the standards listed below, were run on the same slab gel. The standards were bovine serum albumin $\left(M_{\mathrm{r}}=68,000\right)$, lactate dehydrogenase $\left(M_{\mathrm{r}}=35,000\right)$, cytochrome $c\left(M_{\mathrm{r}}=13,000\right)$, and delipidated, purified, feline PNS myelin obtained by the method of Norton and Poduslo (1973). Approximately $150 \mu \mathrm{g}$ of protein were electrophoresed on each channel of the running gel for $5 \mathrm{hr}$ at $15 \mathrm{~mA}$. Following electrophoresis the gels were 


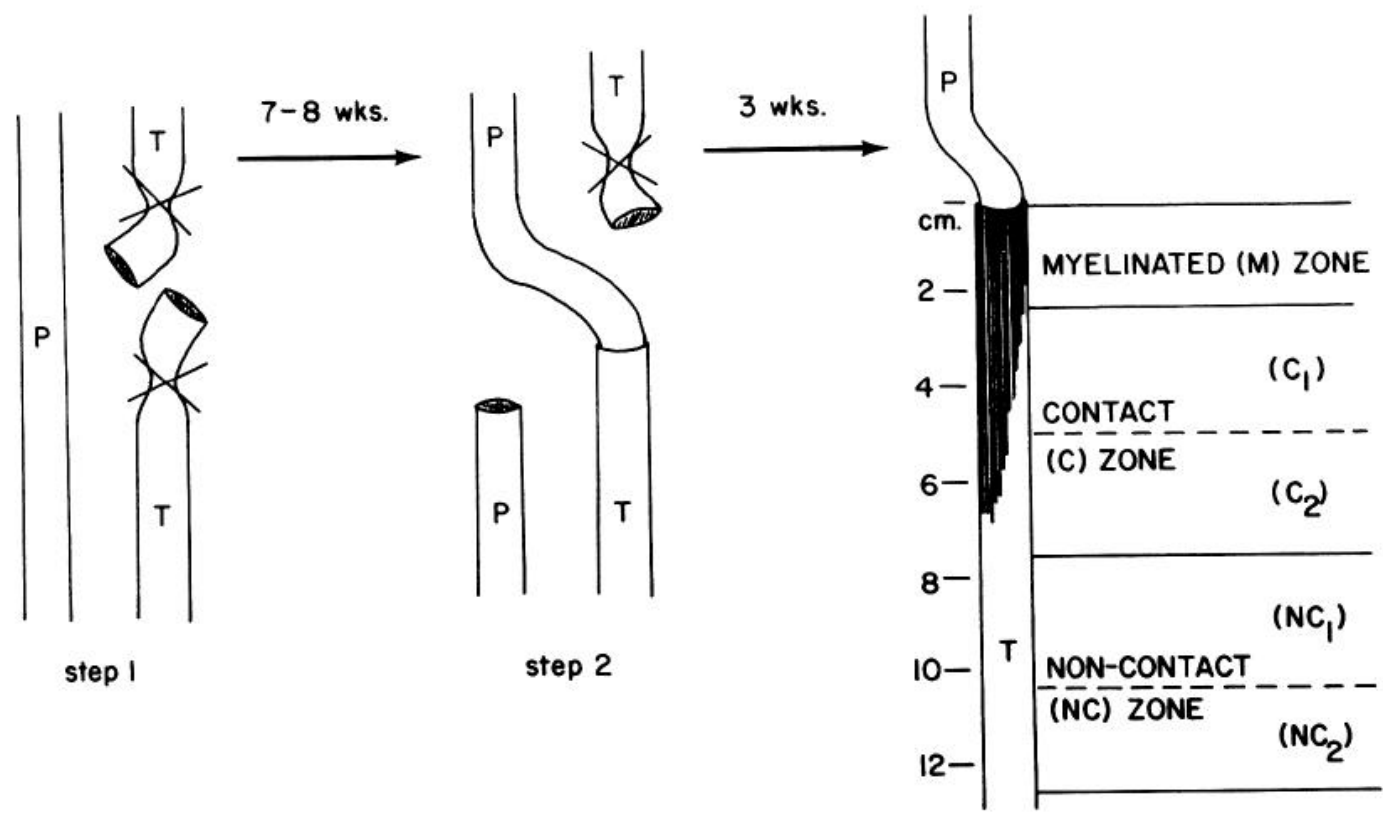

(1)
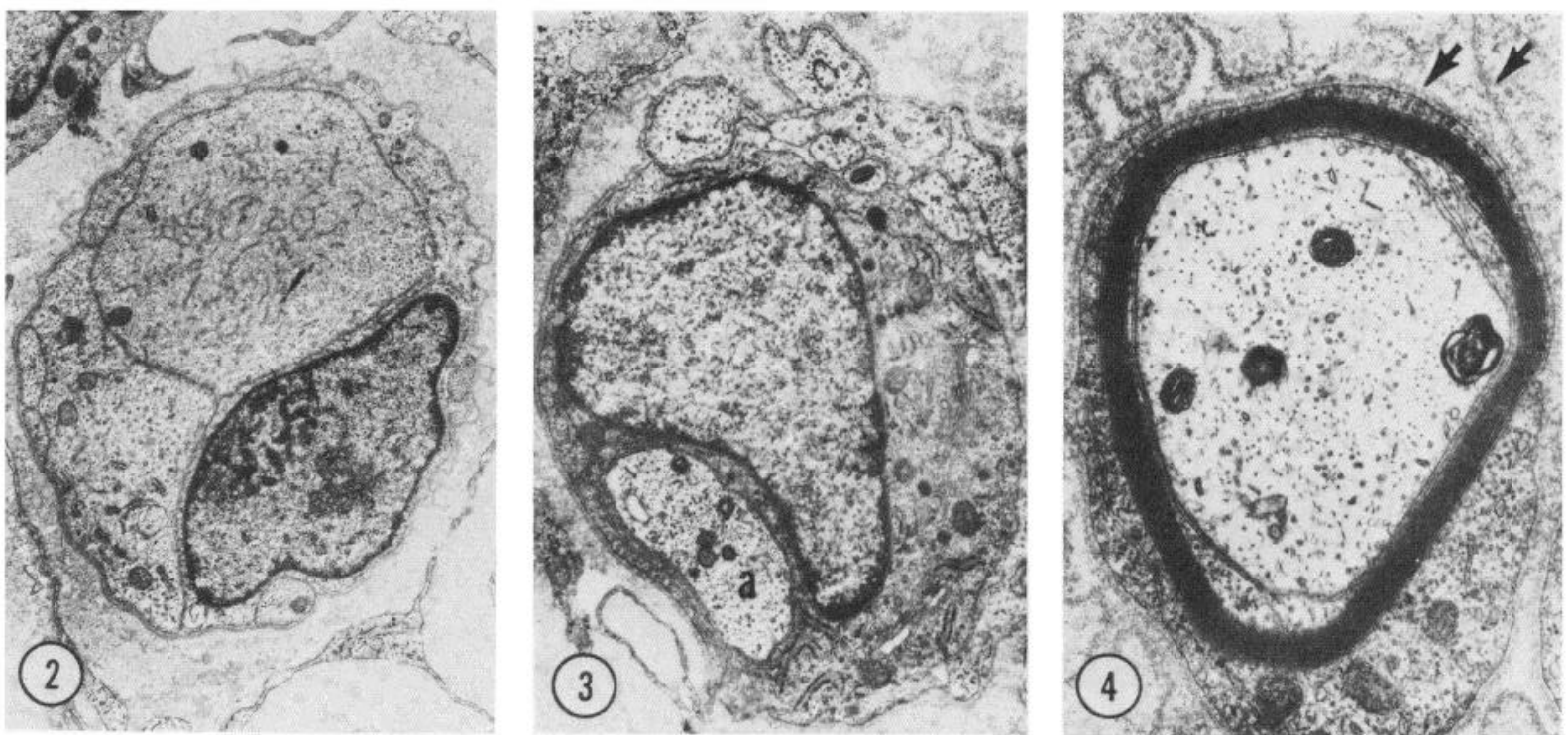

Figure 1. Diagram of the surgical protocol used to separate spatially the temporal sequence of nerve fiber regeneration. Step 1 involves double ligation and transection of the cat tibial $(T)$ nerve in the upper thigh. The cut ends of stumps then are reflected and sewn to underlying muscle. Seven to 8 weeks later, the adjacent peroneal nerve $(P)$ is transected, and its proximal stump is coapted with $9 / 0$ sutures to the degenerated (axon- and myelin-free, Schwann cell-enriched) distal stump of the tibial nerve following removal of its ligature (step 2). Three weeks later, three zones are delineated reproducibly in the reinnervated tibial nerve distal stump: a distal noncontact zone $\left(N C_{1,2}\right)$, consisting of Schwann cells free of axons; an intermediate contact zone $\left(C_{1,2}\right)$, where Schwann cells are enveloping newly arrived regenerating axons; and a more mature, myelinated zone $(M)$, where axons are already ensheathed by myelin. (From Politis and Spencer, 1981; used with permission from Chapman and Hall).

Figures 2 to 4 . These micrographs illustrate the ultrastructural appearance of the three zones shown in Figure 1. Figure 2 (zone NC) displays a single Schwann cell column (band of Büngner) composed of overlapping and abutting Schwann cell processes rich in cytoplasmic intermediate filaments and delimited by a single basal lamina. Magnification $\times 6,500$. Figure 3 (zone C) shows a regenerating axon $(a)$ surrounded by a Schwann cell, enriched in Golgi apparatus and rough endoplasmic reticulum, in the preliminary stages of formation of a myelinated nerve fiber. Magnification $\times 10,000$. Figure 4 (zone M) depicts a more mature axon-Schwann cell relationship in which several myelin lamellae have been formed (arrows indicate the original outer and newly developed inner basal laminae). Magnification $\times 14,500$. Figures 2 to 4 are thin epoxy sections, stained with uranyl acetate and lead citrate, of tissue fixed with buffered $5 \%$ glutaraldehyde and $2 \%$ osmium tetroxide. (From Politis and Spencer, 1981; used with permission from Chapman and Hall). 
stained with $0.2 \%$ Coomassie blue and destained with $10 \%$ acetic acid. After destaining, the gels were cut into 1-mm pieces and radioactivity was extracted with Soluene 100 (Packard). Sufficient glacial acetic acid then was added to neutralize the $\mathrm{pH}$ of the samples for reduction of chemoluminescence, and radioactivity was counted several times at least $12 \mathrm{hr}$ following the addition of $10 \mathrm{ml}$ of Aquasol (New England Nuclear). Radioactivity profiles on the gels were "normalized" by considering the 1-mm piece of the gel with the lowest radioactivity value as background radioactivity and determining the radioactivity minus background for each $1-\mathrm{mm}$ segment of the gel. The percentage of total gel radioactivity above background then was calculated for each point and plotted as a function of distance from the gel origin. This was the only method of data analysis that permitted the detection of small differences in the proportion of Schwann cell synthesis devoted to specific proteins. Direct comparison of protein synthesis between control nerves and denervated nerves and between the five segments of reinnervated nerves was thereby achieved. Normal statistical methods of data analysis were not used to compare relative protein synthetic capacities because these methods are invalid for comparison of ratios.

Morphological assessment. A previous paper described the morphological examination of coapted tibialperoneal nerves (Politis and Spencer, 1981).

Immunocytochemistry. One-micrometer sections of Epon-embedded nerves were mounted on glass slides and placed in a $60^{\circ} \mathrm{C}$ oven overnight to adhere sections to the slides. Epon was removed as described by Baskin and coworkers (1979). Minor changes in the technique were made to minimize the destruction of the myelin components. The slides were immersed in $(a)$ a solution of 1 vol of saturated sodium hydroxide plus 2 vol of absolute ethanol for $15 \mathrm{~min}$ with agitation, $(b)$ absolute ethanol (four rinses for $2 \mathrm{~min}$ each), (c) $0.1 \%$ hydrogen peroxide in $0.1 \mathrm{M}$ Tris for 2 to $5 \mathrm{~min}$ to bleach osmium from the section, and $(d) 0.5 \mathrm{M}$ Tris buffer, $\mathrm{pH} 7.6$ (two rinses). Sections were stained immunocytochemically by the unlabeled antibody-enzyme (peroxidase-antiperoxidase) method (L. A. Sternberger et al., 1970) as described for the localization of myclin antigens (N. H. Sternberger et al., 1978a, b, 1979). Primary antisera to $P_{0}, P_{1}, P_{2}$, myelinassociated glycoprotein (MAG), or preimmune serum controls were diluted 1:500. Production and immunocytochemical characterization of $\mathrm{P}_{0}, \mathrm{P}_{2}$ (Trapp et al., 1979), $P_{1}$ (Itoyama et al., 1980), and MAG (N. H. Sternberger et al., 1979) antisera have been described. Incubation in primary antiserum was done at room temperature for 24 to $48 \mathrm{hr}$. After staining, sections were treated with $2 \%$ osmium tetroxide in $0.1 \mathrm{M}$ phosphate buffer for $1 \mathrm{~min}$ to enhance the diaminobenzidine reaction product $(\mathrm{N}$. $\mathrm{H}$. Sternberger et al., 1979). Slides were dehydrated stepwise, immersed in xylene, and mounted in Permount for assessment by light microscopy.

Immunoprecipitation. Nerve segments from contact zones or from unoperated, control nerves were incubated with tritiated leucine or tryptophan. Homogenates were prepared as before, mixed with a small amount of cold myelin and cytochrome $c\left(M_{\mathrm{r}}=14,000\right)$, and electrophoresed as described above but left unstained. Cytochrome $c$ was added as an approximate marker for $\mathrm{P}_{2}$ since these proteins have similar molecular weights and the former can be visualized as a red band. Myelin was included as a cold "carrier" for the subsequent immunoprecipitation procedure (since the amount of endogenous myelin protein in the contact zone was insufficient to be detected by Coomassie blue staining). Cold myelin was run on separate gel slots and stained with Coomassie blue to determine the location of myelin-specific proteins in adjacent, radiolabeled homogenates. Gel regions associated with $\mathrm{P}_{1}, \mathrm{P}_{2}$, and $\mathrm{P}_{0}$ (including $1 \mathrm{~mm}$ on either side of the bands) were removed with a razor blade and homogenized in $1 \mathrm{ml}$ of $1 \mathrm{M}$ ammonium hydroxide. Samples were shaken at room temperature for $3 \mathrm{hr}$, followed by $10 \mathrm{~min}$ of centrifugation in a desk top centrifuge. Supernatants were removed and lyophilized, and the treated material was resuspended in $0.6 \mathrm{ml}$ of phosphate-buffered saline $(\mathrm{pH}$ 7.4). Control rabbit sera or antisera raised against $\mathrm{P}_{1}, \mathrm{P}_{2}$, or $\mathrm{P}_{0}$ (final dilution, 1:1000) were added and samples were incubated at $37^{\circ} \mathrm{C}$ for $1 \mathrm{hr}$ and then at $4^{\circ} \mathrm{C}$ overnight. One hundred microliters of sheep anti-rabbit IgG and of normal rabbit serum (1:2000 final dilution) were added, and the solution was incubated at $4^{\circ} \mathrm{C}$ overnight. Samples then were centrifuged at $100,000 \times g$ at $4^{\circ} \mathrm{C}$. Supernatants were removed and assayed for radioactivity in Aquasol. Pellets (containing precipitated myelin-specific proteins) were dissolved in Soluene 100 and assayed for radioactivity in Aquasol following the addition of acetic acid.

\section{Results}

$S D S-P A G E$. Approximately $80 \%$ of the radioactivity present in the trichloroacetic acid- and ether/ethanolinsoluble material in nerve homogenates was recovered from gel segments after Soluene 100 digestion. The amount of radioactivity layered on each gel is stated in the legends to Figures 5 to 7.

Normal nerves. The electrophoretic protein pattern of normal, desheathed cat nerves displayed prominent Coomassie blue-stained bands at approximately 27,000 , 19,000 , and 14,000 daltons, corresponding, respectively, to the migration of $\mathrm{P}_{0}, \mathrm{P}_{1}$, and $\mathrm{P}_{2}$ proteins from coelectrophoresed, isolated feline PNS myelin, as well as a number of bands of higher molecular weight. Incorporation of labeled amino acids revealed three peaks comigrant with $\mathrm{P}_{0}, \mathrm{P}_{1}$ and $\mathrm{P}_{2}$ (Figs. $5 a$ and $6 a$ ), with $\mathrm{P}_{0}$ being the most heavily labeled. A band co-migrant with $\mathrm{P}_{0}$ also was labeled by tritiated fucose (Fig. $6 a$ ).

Axon- and myelin-free Schwann cell-enriched distal stumps. In contrast to normal nerves, desheathed distal stumps enriched in Schwann cells lacked a Coomassie blue-stained band co-migrant with $\mathrm{P}_{0}$. Radioactivity profiles from regions co-migrating with myelin proteins demonstrated an absence of peaks of incorporated label from tritiated amino acids (Figs. $5 f$ and $6 f$ ) or fucose. A small peak of amino acid-labeled protein(s) migrated to the 22,000 -dalton region.

Reinnervated tibial nerve distal stumps. No marked differences were found in the Coomassie blue staining of gels prepared from myelinated, contact, and noncontact zones (Fig. 5). Staining corresponding to $\mathrm{P}_{0}$ was not found in any of these zones despite the presence of thinly 

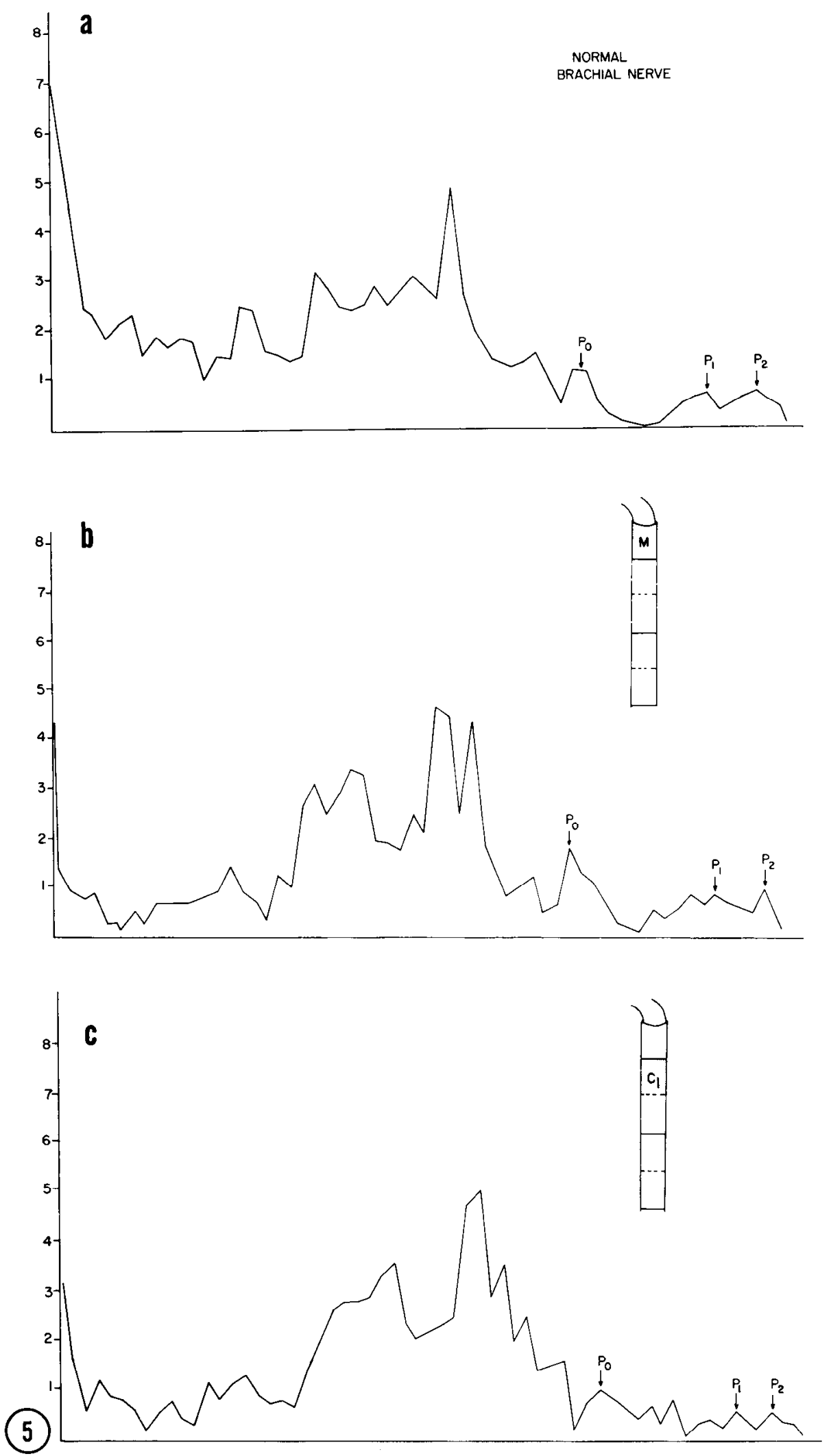

Figure 5. Typical pattern of protein synthesis in cat tibial nerves as measured by $\left[{ }^{3} \mathrm{H}\right]$ leucine incorporation. $a$, Normal brachial nerve (approximately $100,000 \mathrm{dpm} / \mathrm{gel}$ ) displays three peaks of label in proteins co-migrant with myelin-associated proteins $\mathrm{P}_{0}, \mathbf{P}_{1}$, and $\mathrm{P}_{2} . b$ to $e$, Reinnervated distal stumps (approximately 50,000 dpm/gel) show protein peaks co-migrant with myelin proteins $\left(\mathrm{P}_{0}, \mathrm{P}_{1}\right.$, and $\left.\mathrm{P}_{2}\right)$ in the myelinated $(M)$ zone $(b)$. $c$, The proximal portion of the contact zone $\left(C_{1}\right)$ displays peaks of similar size co-migrant with $\mathrm{P}_{1}$ and $\mathrm{P}_{2}$ and a peak co-migrant with $\mathrm{P}_{0} . d$, The distal portion of the contact zone $\left(C_{2}\right)$ exhibits prominent peaks co-migrant with $P_{1}$ and $P_{2}$ approximately twice that seen in more proximal nerve segments. No $\mathrm{P}_{0}$ synthesis is evident. $e$ and $f$, The noncontact zone $\left(N C_{1} ; e\right)$ and 10 -week denervated nerves $(f$, run on separate gels; $50,000 \mathrm{dpm} / \mathrm{gel}$ ) show no evidence of synthesis of any of the myelin-specific proteins. The radioactivity profiles $a$ to $f$ were obtained from approximately 150 $\mu \mathrm{g}$ of protein of total nerve homogenate run on the same slab gel with $30 \mu \mathrm{g}$ of purified myelin alongside. Following SDS-PAGE, the gels were stained with Coomassie brilliant blue. Staining comigrant with $\mathrm{P}_{0}$ was found only in normal nerves and not in myelinated, contact, or noncontact zones of reinnervated nerve stumps. No segment-tosegment variations in reinnervated nerves, in terms of Coomassie blue profiles, were evident. myelinated regenerating axons in the myelinated zone (Politis and Spencer, 1981; Fig. 8, right column). The endogenous pool of $\mathrm{P}_{0}$ present in the myelinated zone was therefore insufficient to be detected with Coomassie blue.

There was no consistent segment-to-segment variation in the total amount of partially delipidated, protein-associated radioactivity in the homogenates of reinnervated stumps. When segments of individual reinnervated nerves were compared with each other by SDS-PAGE, there was consistent segment-to-segment variation in radioactivity profiles (when expressed in terms of the 
Figure 5. Continued.
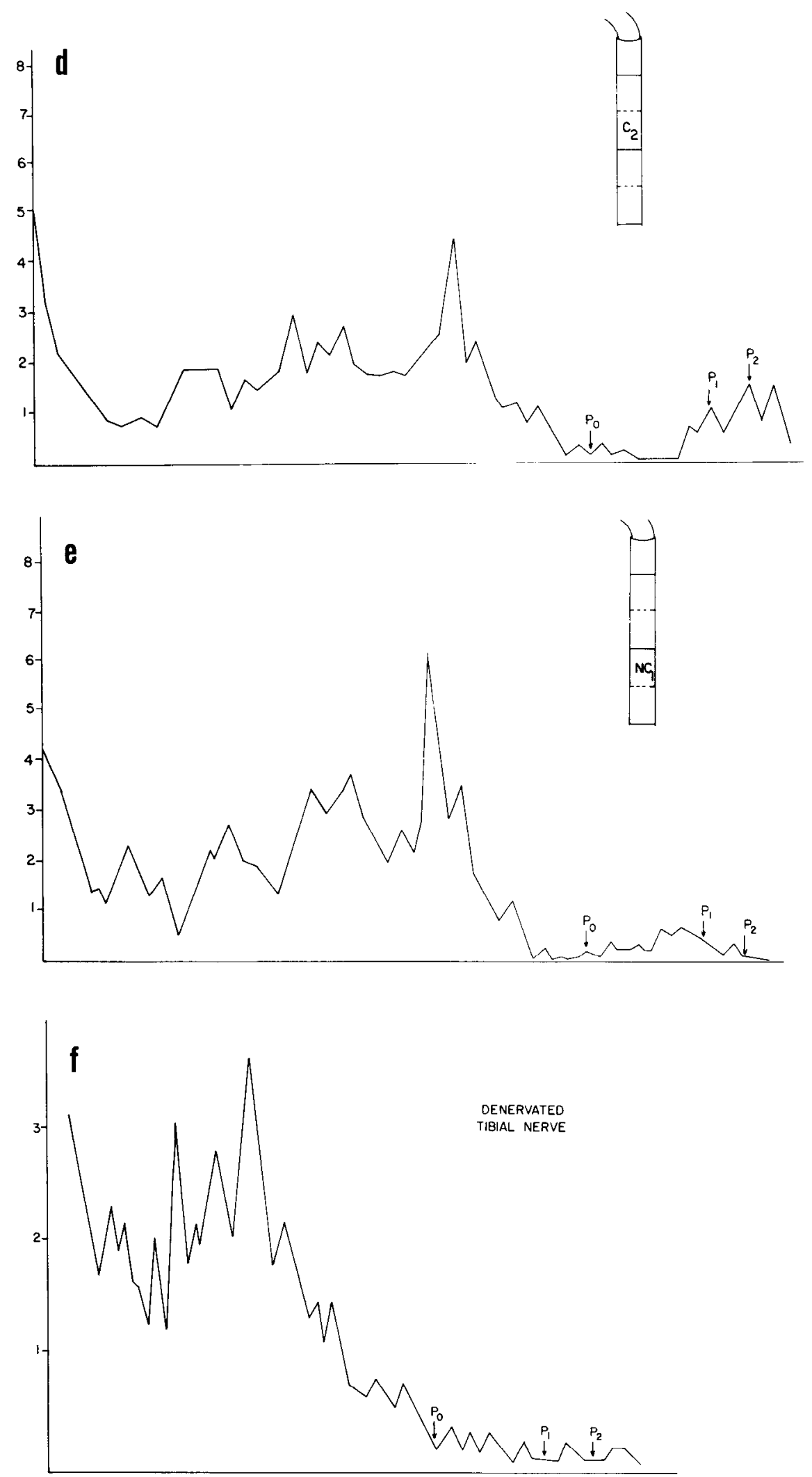

percentage of total gel radioactivity) from incorporated $\left[{ }^{3} \mathrm{H}\right]$ leucine or $\left[{ }^{3} \mathrm{H}\right]$ tryptophan only in peaks co-migrating with $\mathrm{P}_{0}, \mathrm{P}_{1}$, and $\mathrm{P}_{2}$.

The following pattern was seen in all six nerves labeled with amino acids (Figs. 5 and 6). Segments $\mathrm{NC}_{1}$ and $\mathrm{NC}_{2}$-distal regions of the reinnervated nerve stump free of regenerating axons-were similar to each other and displayed no incorporation of label into regions co-migrating with $\mathrm{P}_{0}, \mathrm{P}_{1}$, or $\mathrm{P}_{2}$ proteins, comparable to the findings obtained for control, denervated tibial nerve stumps. By contrast, the myelinated zone, containing Schwann cells elaborating myelin lamellae around regen- 

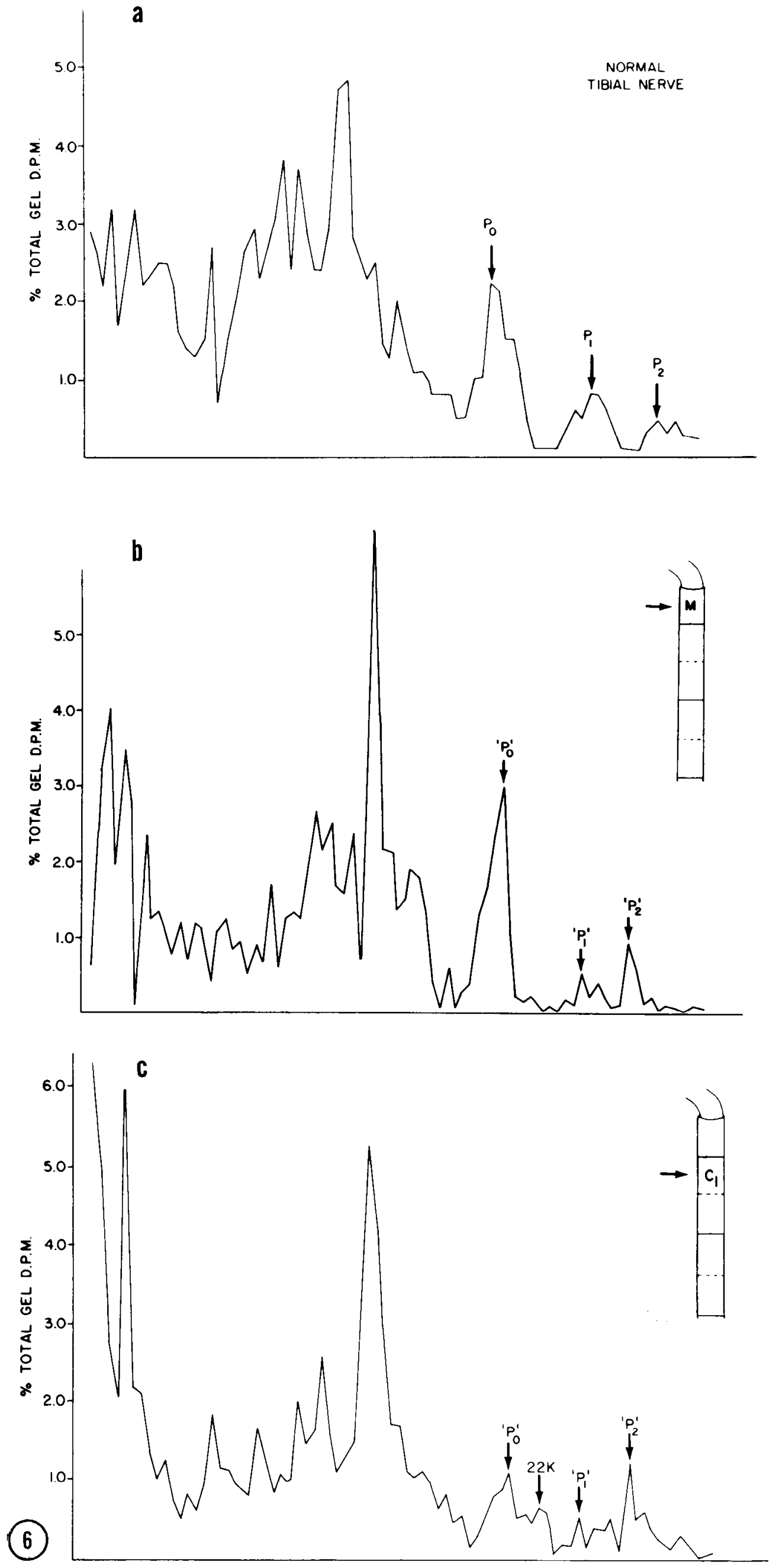

Figure 6. Typical pattern of protein synthesis in cat tibial nerves as measured by $\left[{ }^{3} \mathrm{H}\right]$ tryptophan incorporation. $a$, Normal tibial nerves $(40,000 \mathrm{dpm} / \mathrm{gel})$ display three peaks of label in proteins co-migrant with myelinassociated proteins $P_{0}, P_{1}$, and $P_{2}$. $b$ to $e$, Reinnervated distal stumps (approximately 60,000 $\mathrm{dpm} / \mathrm{gel}$ ) show protein peaks comigrant with myelin proteins (' $\mathrm{P}_{0}$,' ' $\mathrm{P}_{1}$,' and ' $\mathrm{P}_{2}$ ') in the myelinated $(M)$ zone $(b) . c$, The proximal portion of the contact zone $\left(C_{1}\right)$ displays peaks of similar size co-migrating with $\mathrm{P}_{1}$ and $\mathrm{P}_{2}$ and a smaller peak co-migrating with $\mathrm{P}_{0} . d$, The distal portion of the contact zone $\left(C_{2}\right)$ exhibits prominent peaks co-migrant with myelin basic proteins. Little or no radioactivity is seen co-migrating with $\mathrm{P}_{0}$. No evidence of myelin protein synthesis was found distally $\left(e, N C_{1}\right)$, but an unidentified 22,000-dalton peak appeared in this zone and in control, degenerated nerves. $f$, Ten-week degenerated (axon- and myelin-free Schwann cell-enriched) distal stumps $(50,000 \mathrm{dpm} /$ gel) contain no significant radioactivity comigrant with $\mathrm{P}_{0}, \mathrm{P}_{1}$, or $\mathrm{P}_{2}$. 


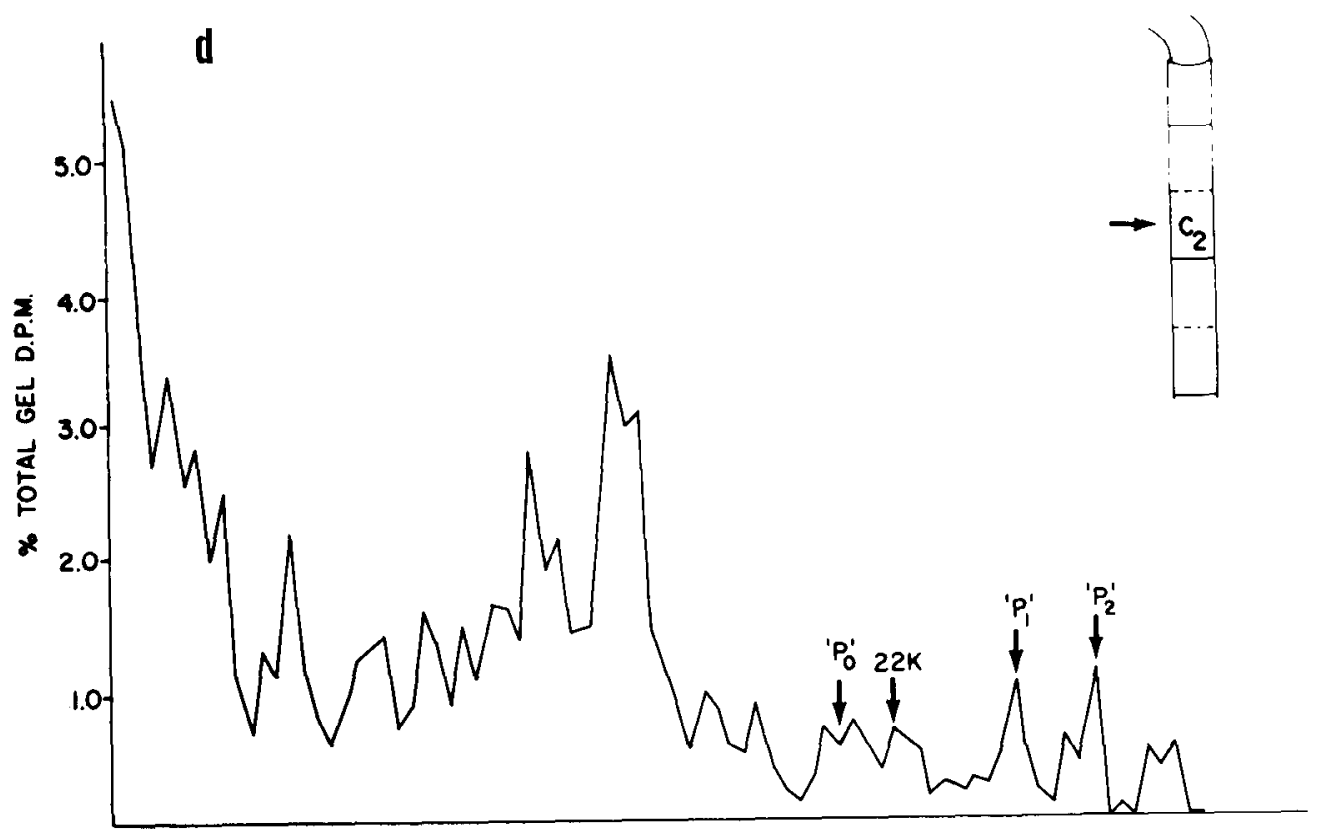

Figure 6. Continued.
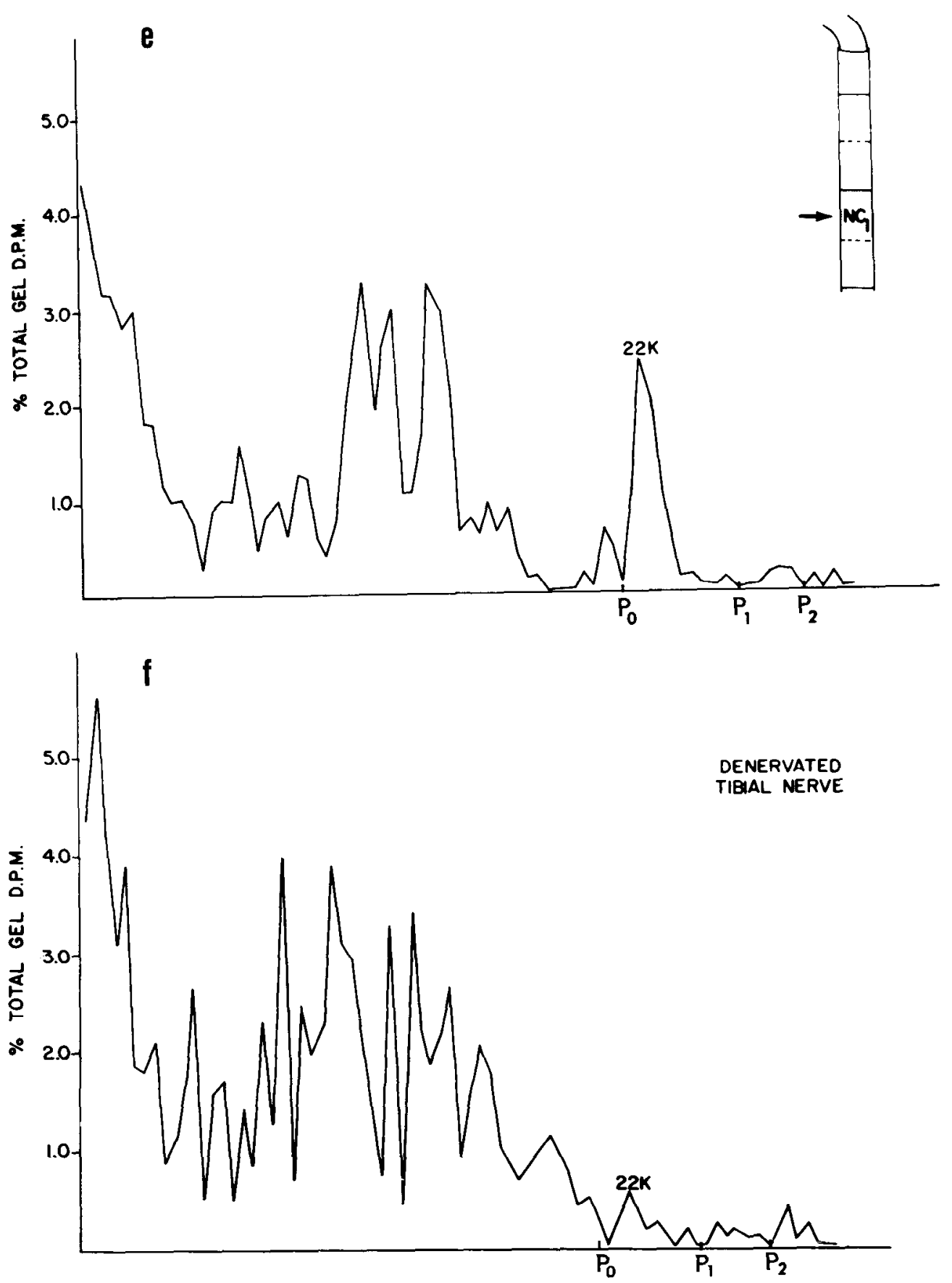

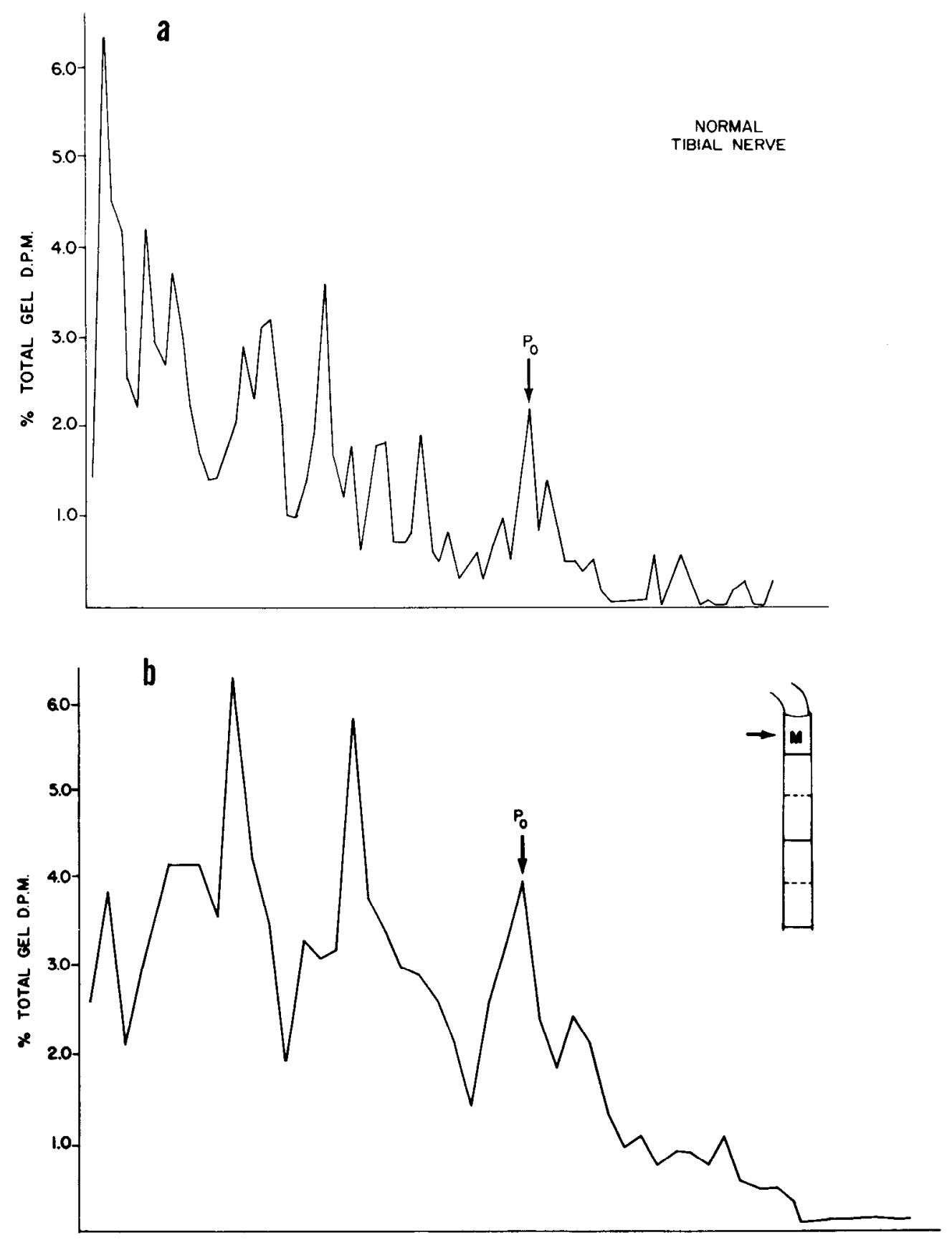

Figure 7. Typical pattern of glycoprotein synthesis in cat tibial nerves as measured by $\left.{ }^{3} \mathrm{H}\right]$ fucose incorporation. $a$, Normal tibial nerves $(7,000$ $\mathrm{dpm} / \mathrm{gel}$ ) display a peak of radioactivity co-migrant with the myelin glycoprotein $\mathrm{P}_{0} . b$ to $e$, Reinnervated distal stumps only show peaks comigrant with $\mathbf{P}_{0}$ in the myelinated $(M ; b)$ and proximal contact $\left(C_{1} ; c\right)$ zones (approximately $1,400 \mathrm{dpm} /$ gel). More distal regions of the nerve $\left(C_{2}\right.$ $(d)$ and $N C_{1}(e) ; 6,000 \mathrm{dpm} /$ gel) display no peaks co-migrant with $\mathrm{P}_{0} . f$, Ten-week denervated nerve.

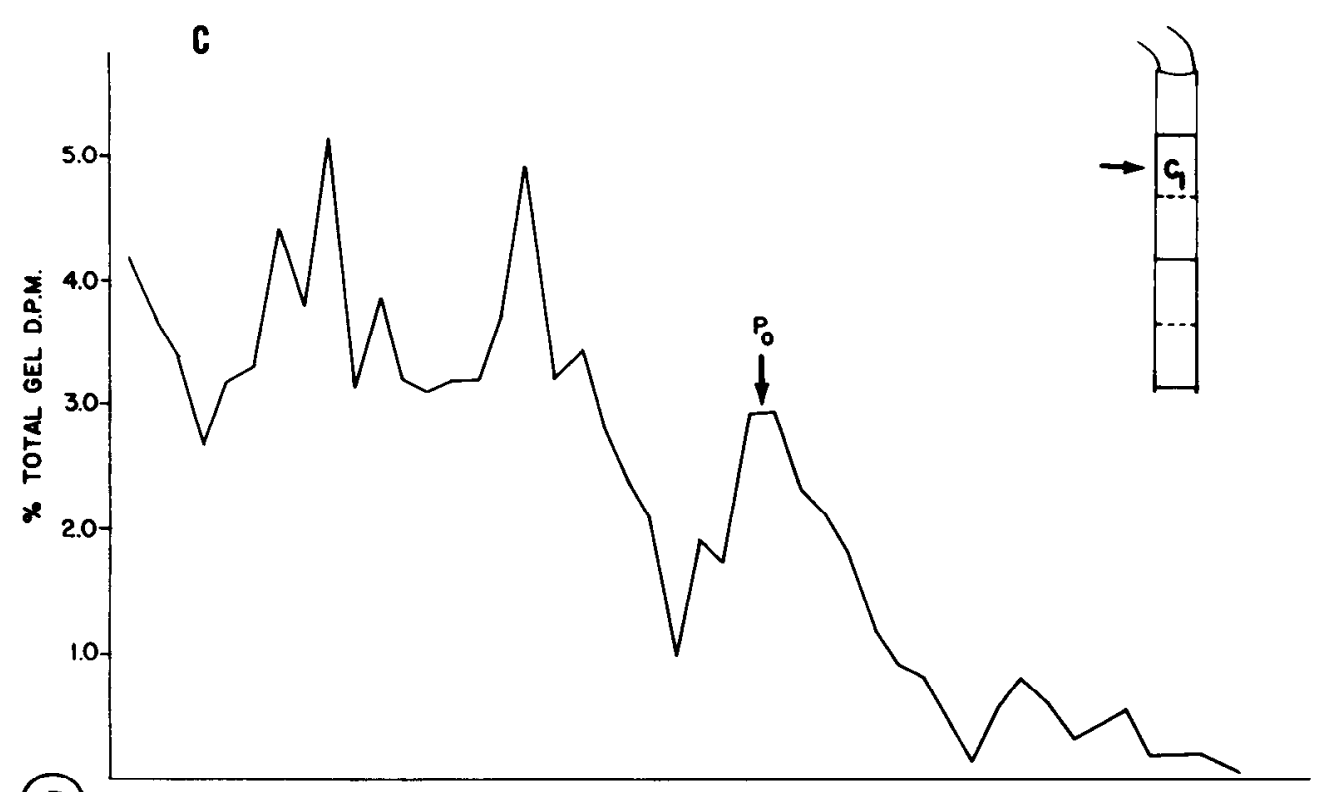




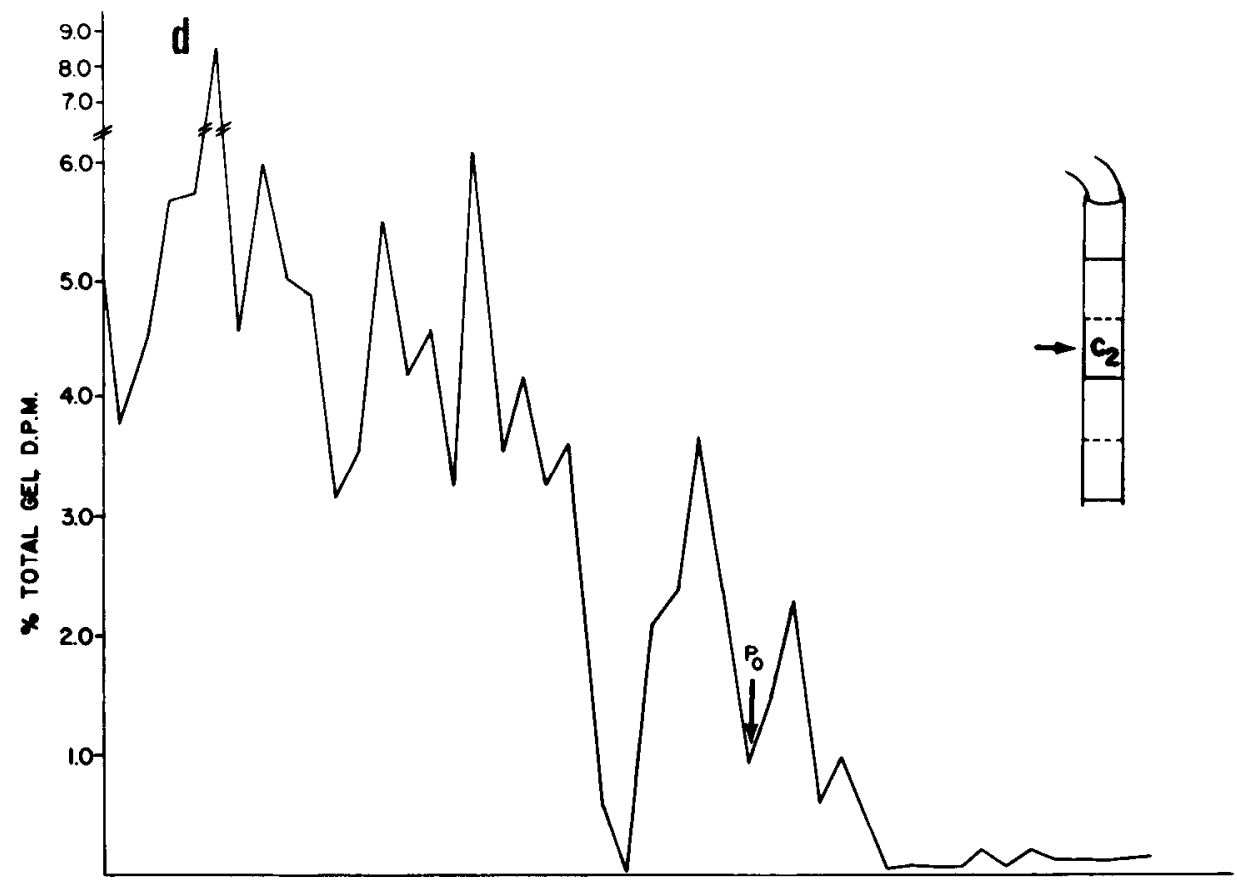

Figure 7. Continued.
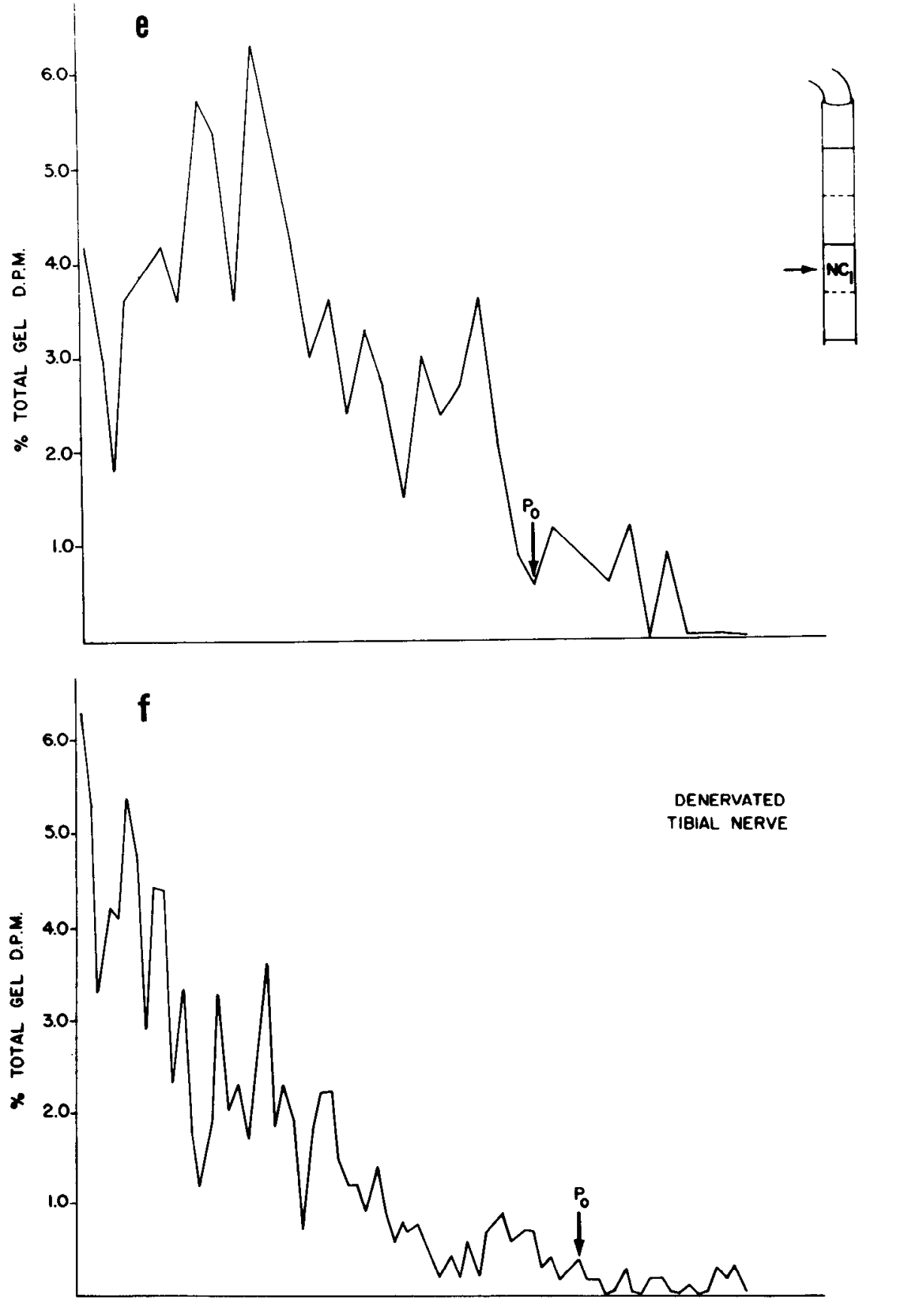

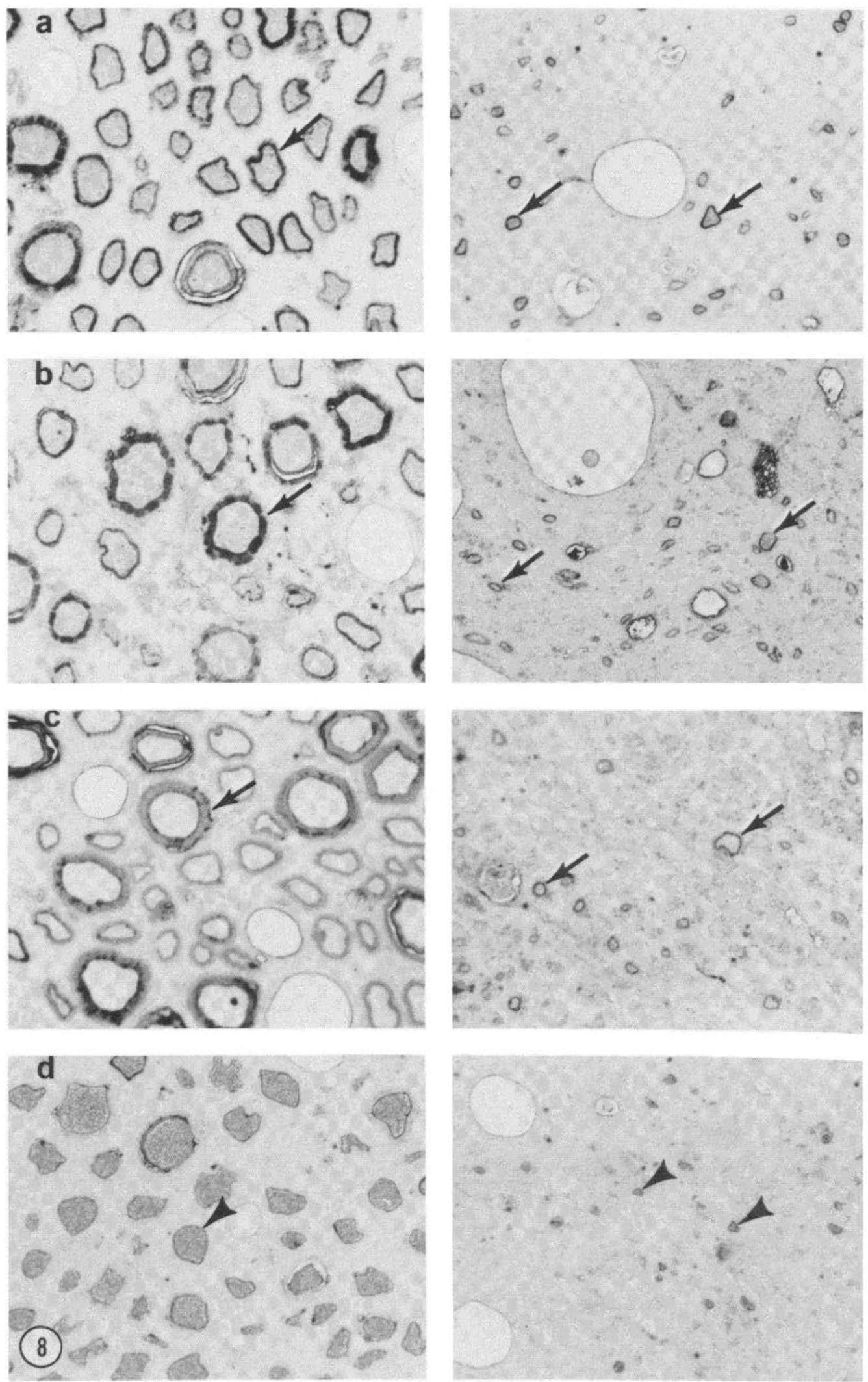

Figure 8. Immunohistochemical staining of reinnervated tibial and unoperated sural nerves. Staining with antibody to myelinassociated proteins in unoperated sural nerve ( first column) and reinnervated tibial nerves 1.0 (second column), 3.0 (third column), and 9.0 ( fourth column) $\mathrm{cm}$ from the position of peroneal-tibial nerve coaptation (corresponding to the myelin, axon contact, and noncontact zones, respectively). Staining with antibody to $\mathrm{P}_{0}, \mathrm{P}_{1}$ and $\mathrm{P}_{2}$ is shown in rows $a$, $b$, and $c$, respectively. Stain is seen over myelin sheaths in the control and the myelinated zone of reinnervated nerves (arrows). No specific staining is observed in axon contact or noncontact regions except for that associated with residual myelin debris (from preceding Wallerian degeneration) in endoneurial phagocytes. Macrophages containing stain are more prominent in the distal noncontact zone (asterisks). Specific staining with MAG (row d) is seen in control nerves and myelinated regions of reinnervated tibial nerves. Specific staining with MAG (arrowheads) is seen in control nerves and myelinated regions of reinnervated tibial nerves but not in more distal regions of the reinnervated tibial nerve (lower panel, $d$ ). These are 1- $\mu$ m epoxy sections stained with toluidine blue. Magnification $\times 600$. 

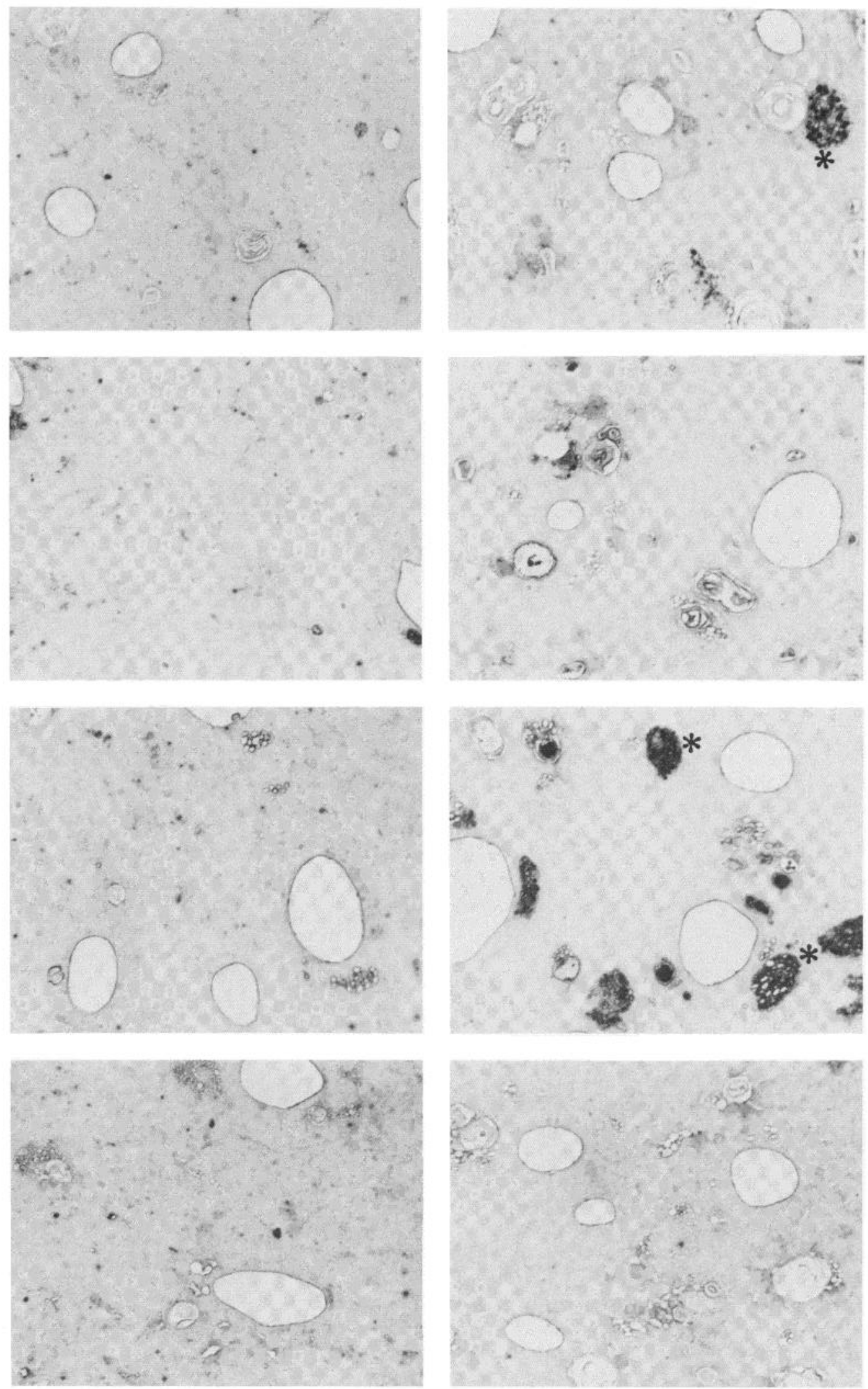

Figure 8. Continued.

erating axons, displayed amino acid-labeled peaks comigrating with $\mathrm{P}_{1}$ and $\mathrm{P}_{2}$ : tritium incorporation also was present in the band co-migrating with $\mathrm{P}_{0}$ despite the absence of Coomassie blue staining in this region of the gel. The two noncontact zones, segments $\mathrm{C}_{1}$ and $\mathrm{C}_{2}-$ regions corresponding to regenerating axons in contact with Schwann cells lacking myelin lamellae-also displayed label co-migrating with $\mathrm{P}_{1}$ and $\mathrm{P}_{2}$. The sum of 
radioactivity profiles for these co-migrant proteins was, in five out of six cases, larger in contact segments $C_{1}$ or $\mathrm{C}_{2}$ than in the myelinated zone $(\mathrm{M})$. Amino acid- and fucose-labeled peaks co-migrating with $\mathrm{P}_{0}$ were seen in the myelinated zone and in the contact zone $\mathrm{C}_{1}$ (Figs. 5 to 7 ). In all cases, no definable radioactive peaks corresponding to $\mathrm{P}_{0}$ were observed in $\mathrm{C}_{2}$. However, in one instance (Fig. $6 d$ ), a slightly elevated trough of radioactivity corresponding to $\mathrm{P}_{0}$ was observed.

In summary, $(a)$ the noncontact zone contained no radioactivity co-migrating with myelin-specific proteins; (b) the axon-Schwann cell contact zone displayed amino acid label co-migrating with $\mathrm{P}_{1}$ and $\mathrm{P}_{2}$ (distally) and fucose-derived label co-migrating with $\mathrm{P}_{0}$ (proximally), and $(c)$ the myelinated zone showed amino acid-derived peaks putatively corresponding to both myelin basic proteins and $\mathrm{P}_{0}$ protein and fucose-derived label co-migrating with this myelin glycoprotein.

Another finding was the intermittent presence of a 22,000 -dalton protein which was strongly labeled by $\left[{ }^{3} \mathrm{H}\right]$ tryptophan (Fig. 6). This protein was most prominent in distal, noncontact regions and, to a lesser degree, in the contact zone and in control denervated tibial nerve stumps. By contrast, the 22,000-dalton protein label was not seen in the myelinated zone or in control nerves. The significance of this finding is unknown. Due to the presence of a broad peak of fucose-labeled radioactivity migrating in the 100,000-dalton region in noncontact zones, it was not possible to monitor the synthesis of MAG protein as a consequence of axonal regeneration.

Immunocytochemical studies. Positive staining with antibodies to $P_{0}, P_{1}, P_{2}$, and $M A G$ proteins was evident in the myelinated zone $(1 \mathrm{~cm}$ from the site of peronealtibial nerve coaptation) and in adjacent normal control sural nerves in the same sections (Fig. 8). Staining for $P_{0}$ and myelin basic proteins was located throughout the myelin sheaths, whereas staining for MAG was restricted to the axon-myelin interface and the outer perimeter of the myelin sheath in both reinnervated tibial and control sural nerves. No specific staining for any of the above proteins was seen in the proximal contact zone $(3 \mathrm{~cm}$ from the point of peroneal-tibial coaptation) or more distal regions or reinnervated tibial nerves. Nevertheless, incorporation of radioactive precursors into proteins comigrant with myelin-specific proteins was evident several centimeters distally in the contact zone where axons and Schwann cells were at an earlier stage of nerve fiber formation and myelin lamellae had yet to develop. The absence of antibody staining in $1-\mu \mathrm{m}$ sections of the contact zone probably was due to insufficient amounts of endogenous pools of myelin proteins which build up with time following axonal stimulation of their synthesis.

Immunoprecipitation studies. Less than $5 \%$ of the radioactive protein extracted from gel regions associated with $\mathrm{P}_{1}, \mathrm{P}_{2}$, or $\mathrm{P}_{0}$ was precipitated by control rabbit sera (Table I). However, the majority of extracted radioactivity incubated with sera raised against myelin-specific protein was precipitated (Table II). This was the case for both contact zone and for normal nerve. Inclusion of small regions of the gel bordering those containing the myelin-specific proteins may account for the small amount of nonprecipitable radioactivity in cases where
TABLE I

Radioactivity in pellets and supernatants of samples subjected to immunoprecipitation by exposure to control rabbit antisera (i.e., not raised against myelin-specific proteins)

\begin{tabular}{crrl}
\hline & Pellet & Supernatant & Precursor \\
\hline \multirow{3}{*}{$\begin{array}{c}\text { Contact zone } \\
\text { P }_{1}\end{array}$} & 206 & 7,186 & \\
& 416 & 10,198 & Leucine \\
$\mathrm{P}_{2}$ & 426 & 7,880 & Tryptophan \\
& 587 & 12,357 & Teucine \\
$\mathrm{P}_{0}$ & 429 & 9,817 & Leucine \\
& 101 & 9,050 & Tryplophan \\
& & &
\end{tabular}

\begin{tabular}{crrl}
$\begin{array}{c}\text { Normal nerve } \\
\mathrm{P}_{1}\end{array}$ & 185 & 14,123 & \\
& 62 & 2,325 & Tryptophan \\
$\mathrm{P}_{2}$ & 465 & 13,366 & Leucine \\
& 587 & 12,357 & Tryptophan \\
$\mathrm{P}_{0}$ & 301 & 14,848 & Leucine \\
& 96 & 3,773 & Tryptophan \\
\hline
\end{tabular}

TABLE II

Radioactivity in pellets and supernatants of samples subjected to immunoprecipitation by exposure to antisera raised against $P_{1}, P_{2}$,

\begin{tabular}{cccl}
\multicolumn{4}{c}{ or $P_{0}$} \\
\hline & Pellet & Supernatant & Precursor \\
\hline Contact zone & & $d p m$ & \\
$\mathrm{P}_{1}$ & & & \\
& 8,000 & 1,750 & Leucine \\
& 3,982 & 1,684 & Leucine \\
& 7,080 & 3,257 & Tryptophan \\
$\mathrm{P}_{2}$ & 4,818 & 826 & Tryptophan \\
& 6,080 & 1,064 & Leucine \\
& 5,280 & 1,618 & Leucine \\
& 8,500 & 3,170 & Tryptophan \\
$\mathrm{P}_{0}$ & 4,090 & 906 & Tryptophan \\
& 8,086 & 1,745 & Leucine \\
& 6,002 & 818 & Tryptophan \\
& 4,818 & 826 & Tryptophan
\end{tabular}

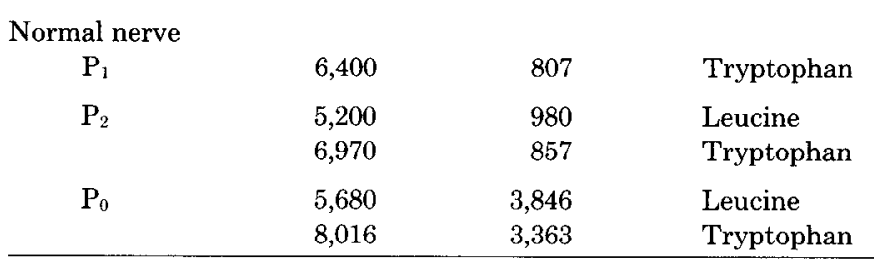

antisera raised against myelin-specific proteins were used.

\section{Discussion}

The present study utilizes a new experimental system to dissect in vivo the temporal sequence of some critical biochemical events that occur before and after regenerating axons induce Schwann cells to differentiate and form myelin. Four major findings are apparent: $(a)$ Schwann cells (or their daughters) which have lost apposition with myelinated axons cease detectable synthesis of myelin-specific proteins $\mathrm{P}_{0}, \mathrm{P}_{1}, \mathrm{P}_{2}$, and (by immunohistochemical assessment) MAG; (b) such "meta- 
bolically naive" Schwann cells (or their daughters) resynthesize proteins co-migrant with, and immunoprecipitated by, myelin-specific proteins upon re-establishment of axonal presence and prior to the formation of myelin lamellae; $(c)$ the synthesis of $P_{1}$ and $P_{2}$ proteins appears to be expressed before that of the major PNS myelin glycoprotein $\mathrm{P}_{0}$; and $(d)$ myelin protein synthesis continues after nerve fiber maturation.

Sensitivity of the radiolabel technique. These findings stem in large part from the use of a radiolabel incorporation technique to monitor the synthetic state of Schwann cells at the time of sacrifice and at ultrastructurally defined stages of nerve fiber formation during regeneration. This approach has the special advantage of being demonstrably more sensitive than SDS-PAGE optical density profiles (Wiggins et al., 1975; Grosswald and Luttges, 1979), immunocytochemical staining (Mirsky et al., 1980), or radioimmunoassay (McDermott and Wiśniewski, 1977), presumably because these other methods depend on the availability of a sufficiently large pool of endogenous protein. By contrast, the appearance of small amounts of radiolabel co-migrant with myelin-specific proteins, positively identified by immunoprecipitation, signals the initiation of their synthesis at a time when Coomassie blue staining of SDS gels and immunocytochemistry are negative and before the appearance of ultrastructurally demonstrable myelin lamellae. Previous immunochemical and immunocytochemical methods designed to determine endogenous pools of protein (Brockes et al., 1980, Mirsky et al., 1980) have only been able to detect myelin proteins $\mathrm{P}_{0}$ and $\mathrm{P}_{1}$ in developing nerves at a time when a small portion of axons is surrounded by myelin lamellae (Webster et al., 1973). Additional evidence of the special sensitivity of the radiolabel approach comes from the observation of Fryxell (1980) on sulfatide synthesis by Schwann cells in vitro. In this experiment, radiolabel incorporation into sulfatide, as identified by migration coefficient, was evident for more than 2 weeks after Schwann cells were dissociated from axons; by contrast, immunochemical staining for sulfatide disappeared within a few days of dissociation (Mirsky et al., 1980).

The naive Schwann cell. The interpretation of this study rests, in part, on the concept that axon-free Schwann cells in permanently denervated nerve stumps do not manufacture myelin components. This idea was suggested by morphological and biochemical (SDSPAGE and radioimmunoassay) studies which demonstrated the gradual removal of myelin and myelin proteins in the distal stumps of transected nerves (e.g., McDermott and Wiśniewski, 1977; Weinberg and Spencer, 1978; Spencer, 1979). Recent immunochemical studies (Brockes et al., 1980; Mirsky et al., 1980) also have demonstrated the loss of myelin-specific proteins in primary cultures of Schwann cells within days of their dissociation from axonal elements in neonatal rat nerve. The present results support the concept that Schwann cells in vivo do not synthesize myelin proteins in the absence of axons. Our failure to detect amino acid-derived label co-migrant with myelin proteins in control denervated nerves is a sensitive indicator of the state of the resident Schwann cells. Thus, it is concluded that the synthesis of detectable myelin-specific proteins does not occur in Schwann cells free of axons.

Axon-dependent initiation of myelin protein synthesis. It has been well established by morphological criteria that Schwann cells resident in chronically denervated tibial distal stumps elaborate myelin lamellae when challenged by axons regenerating from the proximal stump of a freshly severed peroneal nerve (Politis and Spencer, 1981). This model has been used here to separate the temporal sequence of axon-Schwann cell interaction during nerve fiber regeneration in the absence of the changes associated with nerve fiber loss and Schwann cell activation that accompany Wallerian degeneration.

Detectable synthesis of proteins co-migrant with $\mathrm{P}_{0}, \mathrm{P}_{1}$ and $\mathrm{P}_{2}$ myelin proteins only occurred in regions of nerve in which regenerating axons were present. Immunohistochemical studies revealed the presence of these proteins and MAG in thinly myelinated, regenerating fibers. Distal regions enriched in Schwann cells, but free of axons, were identical to control denervated nerves with respect to the lack of detectable synthesis of these proteins and of specific immunocytochemical reaction product. These data are consistent with the concept that axons instruct Schwann cells to initiate the production of myelin proteins promptly after the establishment of axonal association (Spencer, 1979).

The absence of detectable synthesis of proteins comigrant with $\mathrm{P}_{0}, \mathrm{P}_{1}$, or $\mathrm{P}_{2}$ distal to the axon front suggests that axons do not induce Schwann cells to manufacture new proteins by the release of a trophic factor active over centimeter distances. These data therefore would favor the hypothesis that axonal regulation of Schwann cell metabolism requires cell-to-cell apposition. This might be mediated by membrane-membrane interaction between the surfaces of the two cells and/or by the transfer of an axonally transported factor(s) to Schwann cells (Spencer and Weinberg, 1978). In considering these hypotheses, it should be borne in mind that Schwann cells in normal nerves from adult cats display ongoing synthesis of proteins co-migrant with myelin proteins (in the presence of immunohistochemical staining for $\mathrm{P}_{0}, \mathrm{P}_{1}, \mathrm{P}_{2}$, and MAG proteins) unless axonal contact is lost. Furthermore, the axon retains its capacity to stimulate Schwann cells to elaborate myelin lamellae following localized demyelination (Spencer et al., 1975). Thus, it seems likely that axons from myelinated fibers are able to induce Schwann cell myelin protein synthesis throughoul adult life.

Temporal sequence of myelinogenesis. The synthesis of myelin-associated proteins appeared to be highly active prior to the formation of myelin lamellae. The synthesis of proteins co-migrant with myelin basic proteins was expressed following axonal association with Schwann cells before the synthesis of protein co-migrant with $\mathrm{P}_{0}$ became optimal. Little or no $\mathrm{P}_{0}$ synthesis was evident in the distal contact zone, while basic protein synthesis was evident in that region. This could represent a longer latency for the expression of $P_{0}$ synthesis than for basic protein synthesis (with the program for all proteins being initiated at the same time) or temporal differences in the stimulation of their synthesis.

Utility of model. The surgical preparation used in the 
present study also has been used to assay mitotic activity during axonal regeneration and myelinogenesis in vivo (Pellegrino et al., 1980). Thymidine incorporation (presumably in Schwann cells) is significantly higher in regions of distal stumps associated with regenerating axons (axon contact and myelinated zones) than in either distal axon-free regions (noncontact zones) or axon-free distal nerve stumps. This observation, in conjunction with the results of the present study, suggests that, upon contact, axons exert profound effects on Schwann cell metabolism prior to the formation of myelin lamellae.

In summary, a new experimental approach has been used to characterize Schwann cell protein synthesis as a function of axonal contact and myelination. Further exploitation of this model might help to illuminate both the molecular basis of myelin formation during development and regeneration and the etiologies of genetic and toxic perturbations of myelination.

\section{References}

Baskin, D. G., S. L. Erlandsen, and J. A. Parsons (1979) Immunocytochemistry with osmium-fixed tissue. I. Light microscopic localization of growth hormone and prolactin with the unlabeled antibody-enzyme method. J. Histochem. Cytochem. 27: 867-872.

Brockes, J. P., M. C. Raff, J. Nichiguchi, and J. Winter (1980) Studies on cultured rat Schwann cells. II. Assays for peripheral myelin proteins. J. Neurocytol. 9: 67-77.

Fryxell, K. J. (1980) Synthesis of sulfatide by cultured rat Schwann cells. J. Neurochem. 35: 1461-1464.

Greenfield, S., S. Brostoff, E. H. Eylar, and P. Morell (1973) Protein composition of myelin of the peripheral nervous system. J. Neurochem. 20: 1207-1217.

Grosswald, D. E., and M. W. Luttges (1979) Changes in sciatic nerve protein composition during postnatal development. Dev. Neurosci. 2: 51-64.

Inouye, M. (1971) Internal standards for molecular weight determinations of proteins by polyacrylamide gel electrophoresis. J. Biol. Chem. 246: 4834-4838.

Itoyama, Y., N. H. Sternberger, M. W. Kies, S. R. Cohen, E. P. Richardson, Jr., and H. deF. Webster (1980) Immunocytochemical method to identify myelin basic protein in oligodendroglia and myelin sheaths of the human nervous system. Ann. Neurol. 7: 157-166.

Laemmli, U. K. (1970) Analysis of $\mathrm{T}_{4}$ phage proteins by gel electrophoresis. Nature 227: 680-684.

McDermott, J. R., and H. M. Wiśniewski (1977) Studies on the myelin protein changes and antigenic properties of rabbit sciatic nerves undergoing Wallerian degeneration. J. Neurol. Sci. 33: 81-94.

Mirsky, R., J. Winter, E. R. Abney, R. Pruss, J. Gavrilovic, and M. C. Raff (1980) Myelin-specific proteins and glycolipids in rat Schwann cells and oligodendrocytes in culture. J. Cell Biol. 84: 483-494.

Norton, W. T., and S. E. Poduslo (1973) Myelination in rat brain: Method of myelin isolation. J. Neurochem. 21: 749-759.

Pellegrino, R. G., M. J. Politis, and P. S. Spencer (1981) Axonassociated mitosis during peripheral nerve regeneration in vivo. J. Cell Biol. 91: 93a.

Politis, M. J., and P. S. Spencer (1981) A method to separate spatially the temporal sequence of axon-Schwann cell interactions during nerve regeneration. J. Neurocytol. 10: 221-232.

Politis, M. J., K. Ederle, and P. S. Spencer (1980) Axon-directed Schwann cell protein synthesis: Use a of new in vivo model. Trans. Am. Soc. Neurochem. 11: 162.

Schröder, J. M. (1975) Degeneration and regeneration of myelinated nerve fibers in experimental neuropathies. In Peripheral Neuropathy, P. J. Dyck, P. K. Thomas, and E. H. Lambert, eds., pp. 337-362, W. B. Saunders, London.

Spencer, P. S. (1979) Neuronal regulation of myelinating cell function. In Society for Neuroscience Symposia. Vol. 4: Aspects of Developmental Neurobiology, J. A. Ferrendelli and G. Gurvitch, eds., pp. 275-321, Society for Neuroscience, Bethesda, MD.

Spencer, P. S., and H. J. Weinberg (1978) Axonal specification of Schwann cell expression and myelination. In The Physiology and Pathobiology of Axons, S. Waxman, ed., pp. 389-405, Raven Press, New York.

Spencer, P. S., H. J. Weinberg, C. S. Raine, and J. W. Prineas (1975) The perineurial window-a new model of focal demyelination and remyelination. Brain Res. 96: 323-329.

Spencer, P. S., H. J. Weinberg, V. Krygier-Brévart, and V. Zabrenetzky (1979) An in vivo method to prepare normal Schwann cells free of axons and myelin. Brain Res. 165: 119-126.

Spencer, P. S., M. J. Politis, R. G. Pellegrino, and H. J. Weinberg (1981) Control of Schwann cell behavior during nerve degeneration and regeneration. In Post-traumatic Peripheral Nerve Regeneration: Experimental and Clinical Implications, A. Gorio, H. Millesi, and S. Mingrino, eds. pp. 411-426, Raven Press, New York.

Sternberger, L. A., P. H. Hardy, Jr., J. J. Cuculis, and H. G. Geyer (1970) The unlabeled antibody enzyme method of immunocytochemistry. Preparation and properties of soluble antigen-antibody complex (horseradish peroxidase-antihorseradish peroxidase) and its use in identification of spirochetes. J. Histochem. Cytochem. 18: 315-333.

Sternberger, N. H., Y. Itoyama, M. W. Kies, and H. deF. Webster (1978a) Immunocytochemical method to identify basic protein in myelin-forming oligodendrocytes of newborn rat CNS. J. Neurocytol. 7: 251-263.

Sternberger, N. H., Y. Itoyama, M. W. Kies, and H. deF. Webster (1978b) Myelin basic protein demonstrated immunocytochemically in oligodendroglia prior to myelin sheath formation. Proc Natl. Acad. Sci. U. S. A. 75: 2521-2524.

Sternberger, N. H., R. H. Quarles, Y. Itoyama, and H. deF. Webster (1979) Myelin associated glycoprotein demonstrated immunocytochemically in myelin and myelin-forming cells of developing rat. Proc Natl. Acad. Sci. U. S. A. 76: 1510-1514.

Trapp, B. D., L. J. McIntyre, R. H. Quarles, N. H. Sternberger, and H. deF. Webster (1979) Immunocytochemical localization of PNS myelin proteins: $P_{2}$ protein is not a component of all PNS myelin sheaths. Proc. Natl. Acad. Sci. U. S. A. 76: 3552-3556.

Webster, H. deF., J. R. Martin, and M. F. O'Connell (1973) The relationships between interphase Schwann cells and axons before myelination: A quantitative electron microscopic study. Dev. Biol. 32: 401-416.

Weinberg, H. J., and P. S. Spencer (1978) The fate of Schwann cells isolated from axonal contact. J. Neurocytol. 7: 555-569.

Wiggins, T. C., J. A. Benjamins, and P. Morell (1975) Appearance of myelin proteins in rat sciatic nerve during development. Brain Res. 89: 99-106. 